\title{
TECHNOLOGICAL STUDIES OF SOME AGRICULTURAL PRACTICES ON THE YIELD AND IT'S QUALITY OF CANOLA (Brassica napus L.)
}

\author{
Aya Z.A. El-Sharawy; Maha M. Abdallaand and Al.S.B.Gaballah \\ Department of Plant Production, Faculty of Technology and Development \\ Zagazig University, Egypt. \\ e.mail:Dr-mahamabdalla@yahoo.com,ayaezzat770@yahoo.com
}

\section{ABSTRACT}

The experimental field was carried out at a Farm of Ghazala Village, Zagazig District, Faculty of Technology and Development (Sharkia Governorate) during 2017/2018 and 2018/2019 growing seasons to study the effect of planting density $(5,10$ and $15 \mathrm{~cm})$ and nitrogen fertilizer levels ( zero, 40, 60 and $80 \mathrm{Kg} \mathrm{N} / \mathrm{fad}$.), on seed, straw yield and its components for three Canola varieties (Serw 4, Serw 6 and Pactol).

The results showed that Pactol variety achieved higher values and significantly increased compared Serw 4, Serw 6 varieties in number of branches and straw yield. Also, the same trend was found in seed yield. Since Pactol variety was high significant gave the higher in seed yield and their components i.e., number of pods / plant, number of seeds / pod, 1000-seed weight ( $g$ ) and seed yield ton / fad., protein and oil \%.

Highly significant differences were found among planting density (5, 10 and $15 \mathrm{~cm})$, equal (335.838, 167.885 and 111.877plant / fad.), in seed and straw yields and its components. Whereas $(15 \mathrm{~cm})$ planting density gave higher in characters in number of branches / plant, straw yield, number of pods / plant, 1000-seed weight (g), seed yield, protein and oil percentages.

Increasing nitrogen levels from zero, 40, 60 and $80 \mathrm{~kg} \mathrm{~N} / \mathrm{fad}$., increased significantly and high significant the studied characters. In general, $80 \mathrm{Kg} \mathrm{N} /$ fad., gave the highest values, followed by 60, 40 and zero (control) $\mathrm{Kg} \mathrm{N} / \mathrm{fad}$., was lowest in the respect.

Conclusively, the results indicated that, seed yield appeared positive and significant or highly significant correlation with number of seeds / pod, 1000-seed weight, straw yield, oil and protein percentage.

Key words: Canola (Brassica napus L.), Planting density, nitrogen fertilization, yield components, seed characters, protein \& oil percentages, correlation. 


\section{INTRODUCTION}

Rapeseed (Brassica napus L.) is important oil crop in the world oil production Canola (Brassica napus L.) is a winter oilseed plant grown in Egypt, its seeds contain about $40 \%$ oil and $23 \%$ protein. Canola oil had high mono-and polyunsaturated fatty acids (oleic, linolenic) content, so it could be used as an edible oil. The seed meal can be used as animal feed or as a crop nutrient source when returned to the field (Gao et al., 2010).

Planting density in rapeseed has shown that is an important factor affecting rapeseed yield. It also governs the yield components and therefore, the yield of individual plant. A uniform distribution of plants per unit area is a prerequisite for yield stability (Diepenbrock, 2000). Consequently, optimum densities for each crop and each environment should be determined by local research.

Nitrogen fertilization is the most important element and a critical limiting factor for Canola production (Jackson, 2000). Canola yield indirectly affected by nitrogen as a result of increasing stem length, number of flowering branches, total plant weight, seeds / pod, number and weight of pods and weight seeds / plant (Taylor et al., 1991).Thus, this investigation aimed to evaluate three Canola varieties under three plant densities and four N. fertilization levels on yield and it's components and quality.

The evaluation of Canola varieties has been studied by several investigators, El-Nakhlawy and Bakhashwain (2009); Al-Doori (2011); Naseri et al., (2012); Sattar et al., (2013) and Farooq et al., (2017) who found significant differences between the studied varieties in seed yield and it's components and quality. Shahin and Valliollah (2009); Ali et al., (2011); Hozayn and El-Mahdy (2017) and Mondal et al., (2018) reported that the tested varieties differed significantly in plant height, number of branches, and relative growth rate (growth characters). Khayat (2015); Farooq et al., (2017) and Mondal et al., (2018) found significance differences between varieties in number of pods / plant, number of seeds / pod, 1000- seed weight and seed yield / fad..

Planting density is one of the most important factor affecting Canola yield Kazemeini et al., (2010), Al-Doori (2011), Al-Doori (2013) and Ali (2020) found significant between studied planting density at some growth parameters, seed yield and it's components like, plant height, number of branches, number of pods / plant, number of seeds / pod, 1000- seed weight and protein and oil \%.

It is well known that nitrogen fertilization plays an important role on the productivity of different field crops. Malidarreh (2010); Kazemeini et al., (2010); Keivanrad and Zandi (2014); Al-Solaimani et al., (2015), Mohamed et 
al., (2017); Alam et al., (2018) and Riar et al., (2020) investigated on some growth characters and seed yield and it's components. Plant height, No. of branches, No. of pods / plant, No. of seeds / pod, 1000- seed weight, protein and oil \%. All these characters were significantly increased due to increasing nitrogen fertilization.

Therefore, this investigation aimed to evaluate the rapeseed of three Canola varieties to applied three planting density and four nitrogen fertilization levels.

\section{MATERIALS AND METHODS}

The experimental field was carried out at a Farm of Ghazala village, Zagazig District, Faculty of Technology and Development, (Sharkia Governorate) during the two successive seasons 2017 / 2018 and 2018 / 2019 to study the effect planting density and $\mathrm{N}$-fertilization on growth, yield and it's components and seed quality for three varieties of Canola.

The experiment included 36 treatments, which were combinations of three varieties (Serw 4, Serw 6 and Pactol) ${ }^{*}$, three plant densities (5, 10 and $15 \mathrm{~cm}$ ), equal (335.838, 167.885 and 111.877 plant / fad.), and four levels of nitrogen i.e., zero, 40, 60 and $80 \mathrm{Kg} \mathrm{N} /$ fad., Canola seeds were shown in rows on $13^{\text {th }}$ and $11^{\text {th }}$ October in the first and second seasons, respectively. The experimental field was fertilized with calcium super phosphate $\left(15.5 \% \mathrm{P}_{2} \mathrm{O}_{5}\right)$ at a rate of $200 \mathrm{Kg}$ / fad., before sowing. Ammonium nitrate (33.5\%) was source of $\mathrm{N}$ - applied. Nitrogen fertilizer for each plot was divided into two equal parts. The first part was applied just after thinning, while the second one was added before the three irrigation. Harvesting was made after 155 days from sowing in the two seasons.

A split - split plot design with three replications was used with sub-sub plot area of $12 \mathrm{~m}^{2}$. The three varieties were assigned to the main plots the splitplots included planting density and the split-split for the four levels of nitrogen.

\section{Data collected:}

At harvest, ten guarded plants were randomly taken to determine the following yield components:

1- Plant height "cm".

2- Number of branches / plant.

3- Number of pods / plant.

4- Number of seeds / pod.

5- 1000-seed weight (gm).

In addition, the central two rows of each plot were harvested to measure:

\footnotetext{
* - The seeds of the tested varieties were obtained from Agricultural Research Center, Ministry of Agricultural, Giza.
} 
1- Straw yield ton /fad.

2- Seed yield ton /fad.

3- Seed quality:

Quality characters were calculated using the method of A.O.AC. (2005).

a) Protein content $\%$.

b) Oil content $\%$.

\section{4-Seed yield analysis:}

\section{The correlation coefficients:}

Analysis of variance was done by using the SAS (2008) system for windows, version 6.311. (Cohort software, Berkeley, CA, USA). In the interaction capital letters were used compare means in rows whereas, small ones were used to compare means in columns. Further, the correlation coefficients among all possible combination of characters were calculated using the method of SPSS (2020).

\section{RESULTS AND DISCUSSION}

\section{1- Straw yield and it's components:}

It is clear from the results in Table (1) that Pactol variety was higher values in number of branches / plant and straw yield in the two seasons and the combined. Similar indicated results were showed by Hozayn and El-Mahdy (2017) and Mondal et al., (2018), But, Ali et al., (2011) indicated that the differences did not reach the level of significant among the varieties in plant height $(\mathrm{cm})$. However, Al-Doori and Hasan (2010), Al-Doori (2011) and Kulachi et al., (2016) found that the tested varieties were different in growth and yield component characters as plant height and number of branches / plant.

Regarding the effect of planting density, the results revealed that number of branches / plant and straw yield differed significantly in both growing seasons and the combined, where $15 \mathrm{~cm}$ planting density recorded higher averages. The relative increase was about $13.20,44.91$ and $140.22 \%$ for plant height, number of branches / plant and straw yield respectively, due to $15 \mathrm{~cm}$ planting density.

Also, nitrogen fertilization had a significant and highly significant effect on plant height, number of branches / plant and straw yield. In general, $80 \mathrm{Kg}$ $\mathrm{N} /$ fad., gave the highest values of plant height, number of branches / plant and straw yield ton / fad., followed by 60, 40 while zero (control) was lowest in the two seasons and the combined. The relative increase in plant height was $37.04 \%$ as well as it was $30.05 \%$ for number of branches / plant and $36.65 \%$ for straw yield due to increasing $\mathrm{N}$-levels from zero to $80 \mathrm{Kg} \mathrm{N} /$ fad., respectively. 


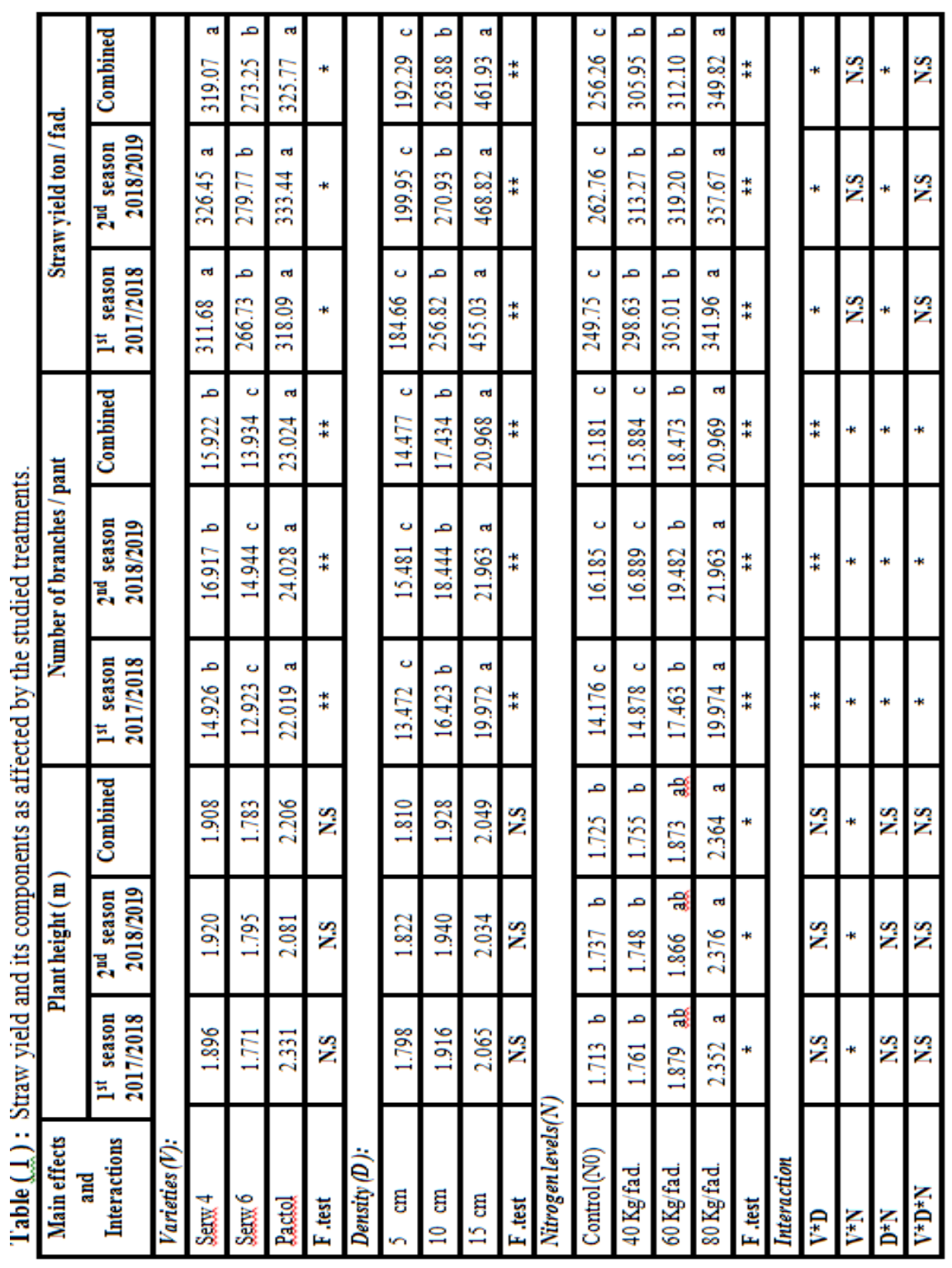


These results are in agreement with those obtained by Elewa et al., (2014), AlSolaimani et al., (2015) and Mohamed et al., (2017).

\section{2-Seed yield and it's components:}

The results in Table (2) showed clearly that highly significant differences among the three varieties were found in seed yield and it's components. Generally, Pactol variety gave higher values in all studies characters i.e., number of pods / plant, number of seeds / pod, 1000-seed weigh (gm) and seed yield ton / fad.,. These results are in a good line with those reported by Khayat (2015), Maha, El-Maleh et al., (2015); Kulanchi et al., (2016); Farooq et al., (2017) and Mondal et al., (2018).

Also, planting density had high significant effect on seed yield and it's components, where planting density of $15 \mathrm{~cm}$ achieved higher increases of seed yield and components. The relative increase was about $15.67 \%, 11.5 \%$ and $156.79 \%$ due to of $15 \mathrm{~cm}$ planting density for number of pods / plant, 1000seed weight (gm) and seed yield ton / fad., respectively.

Regarding the effect of nitrogen fertilization on seed yield and it's component, it is clear from the data that, number of pods / plant, 1000-seed weight (gm) and seed yield were increased highly significant by adding nitrogen, this was true in the two seasons and combined. The relative increase due to increasing $\mathrm{N}$. levels from zero to $80 \mathrm{Kg} \mathrm{N} /$ fad., in number of pods / plant, 1000-seed weight (gm) and seed yield ton / fad., was about $11.74 \%$, $30.49 \%$ and $69.87 \%$, respectively. The obtained results are in agreement with reported by Keivanrad and Zandi (2012); Naderifa and Daneshian (2012); Aminpanah (2013); Al-Solaimani et al., (2015); Farooq et al., (2017) Alam et al., (2018) and Mourad et al., (2021).

Concerning the interaction effects between the investigated factors on seed yield/fad., in the combined data showed significant differences. Mean while the significant interaction between varieties and planting density Table (2-a) show that Pactol variety had higher seed yield compared Serw 4 and Serw 6 under the different plant densities. On the other hand, planting density $(15 \mathrm{~cm})$, tend to increase seed yield / fad., of the three varieties studied (Serw 4, Serw 6 and Pactol). Thus, the highest seed yield 3.229 ton / fad., was achieved by Pactol variety with light planting density of $15 \mathrm{~cm}$.

The significant interaction between planting density and nitrogen fertilization Table $(2-b)$ indicated that $(15 \mathrm{~cm})$ planting density recorded higher seed yield / fad., with $80 \mathrm{Kg} \mathrm{N} /$ fad., On the other hand, all plant densities (5, 10 and $15 \mathrm{~cm}$ ) showed higher seed yield ton / fad., of 1.233, 1.810 and 3.419 with $80 \mathrm{Kg} \mathrm{N} /$ fad., respectively. Thus the higher seed yield of 3.419 was achieved by $15 \mathrm{~cm}$ planting density with $80 \mathrm{Kg} \mathrm{N} /$ fad.. 
J. Product. \& Dev., 26(4),2021

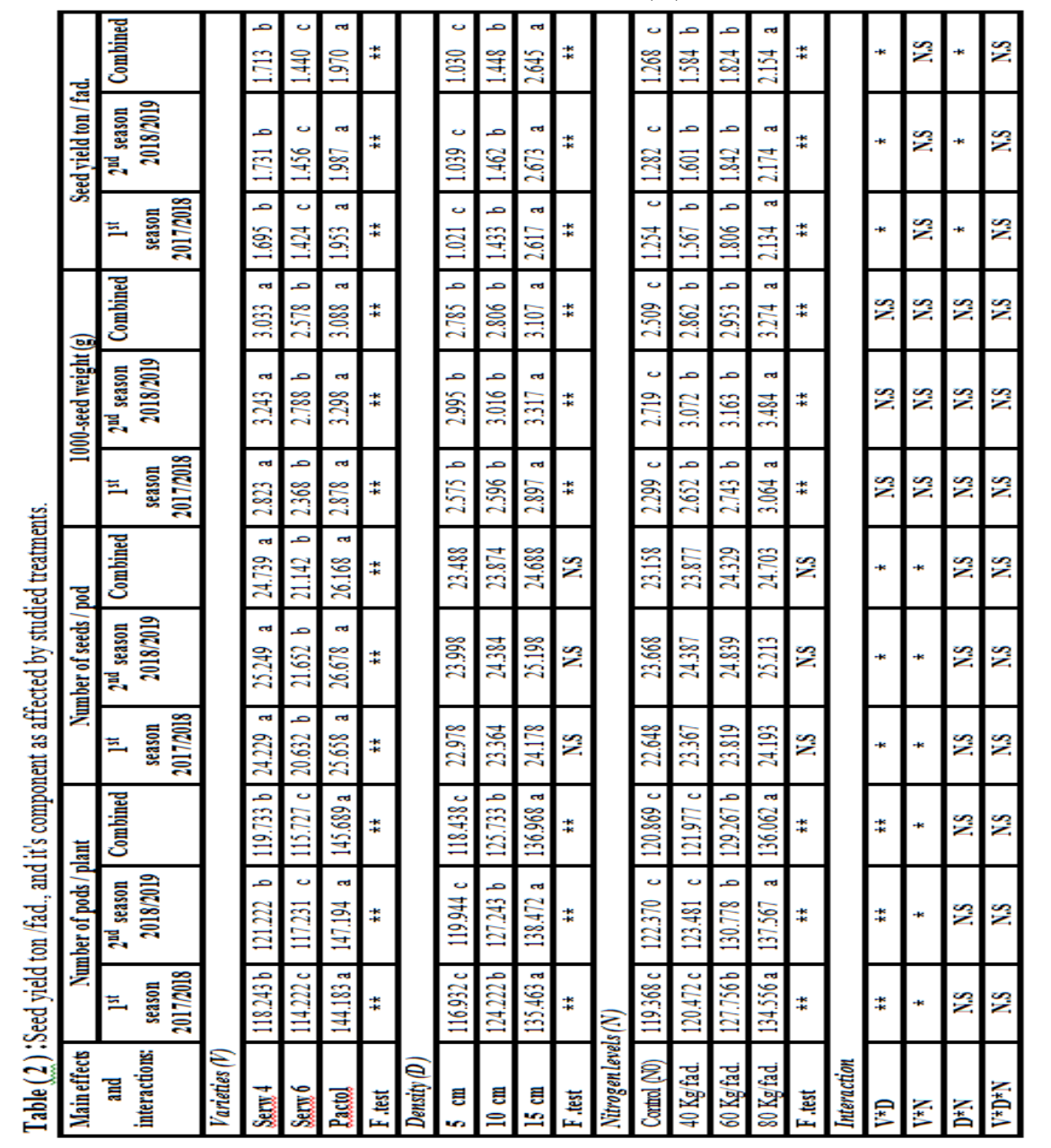


Table ( $2-\mathbf{a})$ : Interaction effect between varieties and planting density (spacing inter rows) on seed yield ton / fad. (Combined data).

\begin{tabular}{|c|c|c|c|}
\hline Varieties $\quad \begin{array}{c}\begin{array}{c}\text { Planting } \\
\text { density }\end{array} \\
\end{array}$ & $\begin{array}{c}\text { D1 } \\
5 \text { CM }\end{array}$ & $\begin{array}{c}\text { D2 } \\
10 \mathrm{CM}\end{array}$ & $\begin{array}{c}\text { D3 } \\
15 \mathrm{CM}\end{array}$ \\
\hline Serw 4 & $\begin{array}{r}\mathrm{C} \\
1.123 \quad \mathrm{a}\end{array}$ & $\begin{array}{c}B \\
1.456 \mathrm{a}\end{array}$ & $\begin{array}{c}A \\
2.560\end{array}$ \\
\hline Serw 6 & $\begin{array}{r}\mathrm{C} \\
\mathbf{0 . 8 5 1} \text { a }\end{array}$ & $\begin{array}{c}\text { B } \\
1.323 \mathrm{a}\end{array}$ & $\begin{array}{c}A \\
2.146 \\
c\end{array}$ \\
\hline Pactol & $\begin{array}{c}\mathrm{C} \\
1.116 \text { a }\end{array}$ & $\begin{array}{c}\text { B } \\
1.564 \text { a }\end{array}$ & $\begin{array}{c}\text { A } \\
3.229 \\
\text { a }\end{array}$ \\
\hline
\end{tabular}

Table ( 2 - b): Interaction effect between planting density (spacing inter rows) and nitrogen levels on seed yield ton / fad. (Combined data).

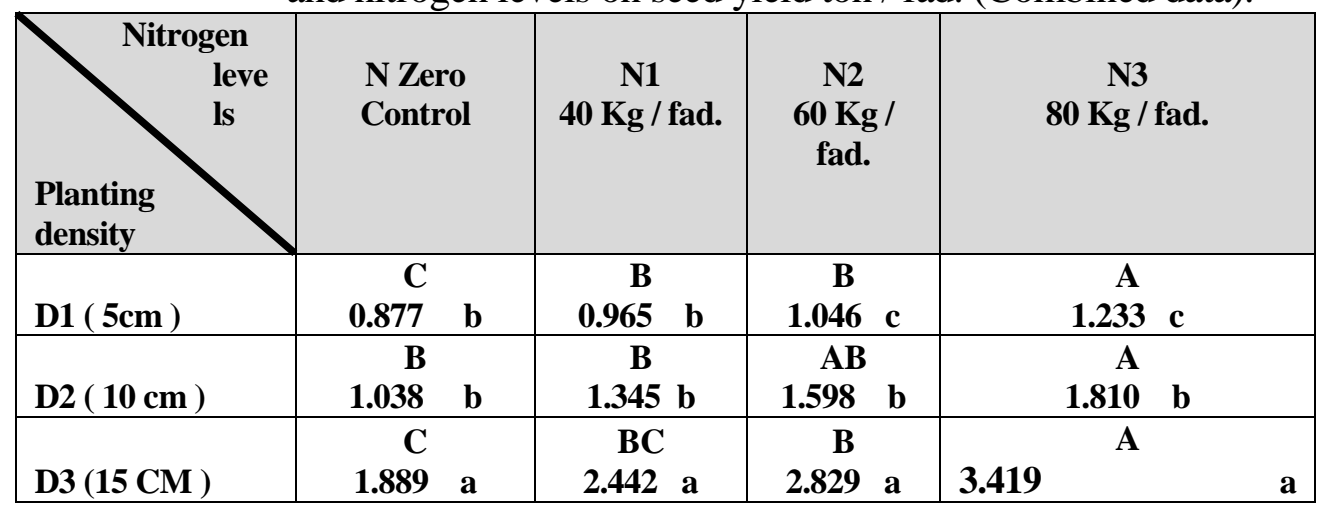

\section{3-Seed quality:}

Concerning the quality properties of Canola seed i.e., protein and oil content $\%$. Data presented in Table (3) showed that the percentage of protein and oil content $\%$ were highly significant by all factors studied.

The results in Table (3) showed clearly that, high significant differences among the three varieties were found in protein and oil \%.

Generally, Pactol variety higher percentage in all the studied characters i.e., protein and oil\%. These results are in a good line with those reported by Ozer (2003-a); Al-Doori (2011); Naseri et al., (2012); Sattar et al., (2013); Elewa et al., (2014); Maha, El-Maleh et al., (2015) and Kulachi et al., (2016).

Also, planting density tested had high significant effect on protein and oil\%, where $(15 \mathrm{~cm})$ planting density their average. The relative increase was about $4.20 \%, 4.661 \%$ due to $(15 \mathrm{~cm})$ planting density for protein and oil\% of the combined, respectively. Similar results were reported by Al-Doori (2011); Keivanrad and Zandi (2012), Naseri et al., (2012) and Al-Doori (2013). But,

Ozer (2003-a) and Junior et al., (2012) found that sowing density did not affected seed quality characters, i.e., protein and oil\%. 
Regarding the effect of nitrogen fertilization on protein and oil \%, it is clear from the data that protein and oil \% were increased high significant by adding $\mathrm{N}$-levels this was found in the two seasons and the combined. The relative increase due to increasing nitrogen from zero (control) to $80 \mathrm{Kg} \mathrm{N} /$ fad., in protein and oil\% was about 9.62\%, 5.49\% for the combined respectively. These results are agreement with those reported by Keivanrad and Zandi (2014); Al-Solimani and Alghabzri (2015); Al-Solimani et al., (2015); Eman, El-Sarag and Hassan (2016) and Riar et al., (2020). But, Mourad et al., (2021) found that nitrogen increase did not effect on oil content $\%$, thus, insignificant Canola seed.

The iteration effects between the investigated factors on protein and oil\% in the combined showed highly significant differences. Meanwhile, the high significant interaction between the three factors studied. The interaction between varieties and planting density, also nitrogen fertilizer in Table (3-a and 3-b) injected that Pactol variety recorded higher protein $\%$ with $(15 \mathrm{~cm})$ planting density and $80 \mathrm{Kg} \mathrm{N} /$ fad., $28.589 \%$ and 28.833, respectively. Likely, interaction between planting density and nitrogen fertilization in Table (3-c) showed that $(15 \mathrm{~cm})$ planting density had higher protein $\%$ with $80 \mathrm{Kg} \mathrm{N} / \mathrm{fad}$., $(27.045 \%)$.

Data in Table (3-d and 3-e) showed the interaction between varieties and planting density and N-levels, Pactol variety recorded the higher oil\% with $(15 \mathrm{~cm})$ planting density and $80 \mathrm{Kg} \mathrm{N} /$ fad., $44.657 \%$ and $45.314 \%$ in the combined, respectively.

Also, the interaction between planting density and N-levels in Table (3-f) showed that $(15 \mathrm{~cm})$ had higher oil\% with $80 \mathrm{Kg} \mathrm{N} /$ fad., (41.038\%).

\section{4-Seed yield analysis:}

\section{The correlation coefficients:}

The interrelationships among seed yield and it's components of Canola as affected by the studied treatments measured as simple correlations are shown in Table (4).

Seed yield was positively and highly significant correlated with most characters studied i.e., number of seeds / pod, 1000-seed weights, straw yield, protein content $\%$. These results are in a good connection with those by Kazemeini et al., (2010) Aminpanan (2013) and Ma. et al., (2015).

Also, in general all correlation coefficients among the studied yield attribute and components were positive and highly significant, except that number of pods, number of branches, plant height whereas coefficients did not reach the significance level. 


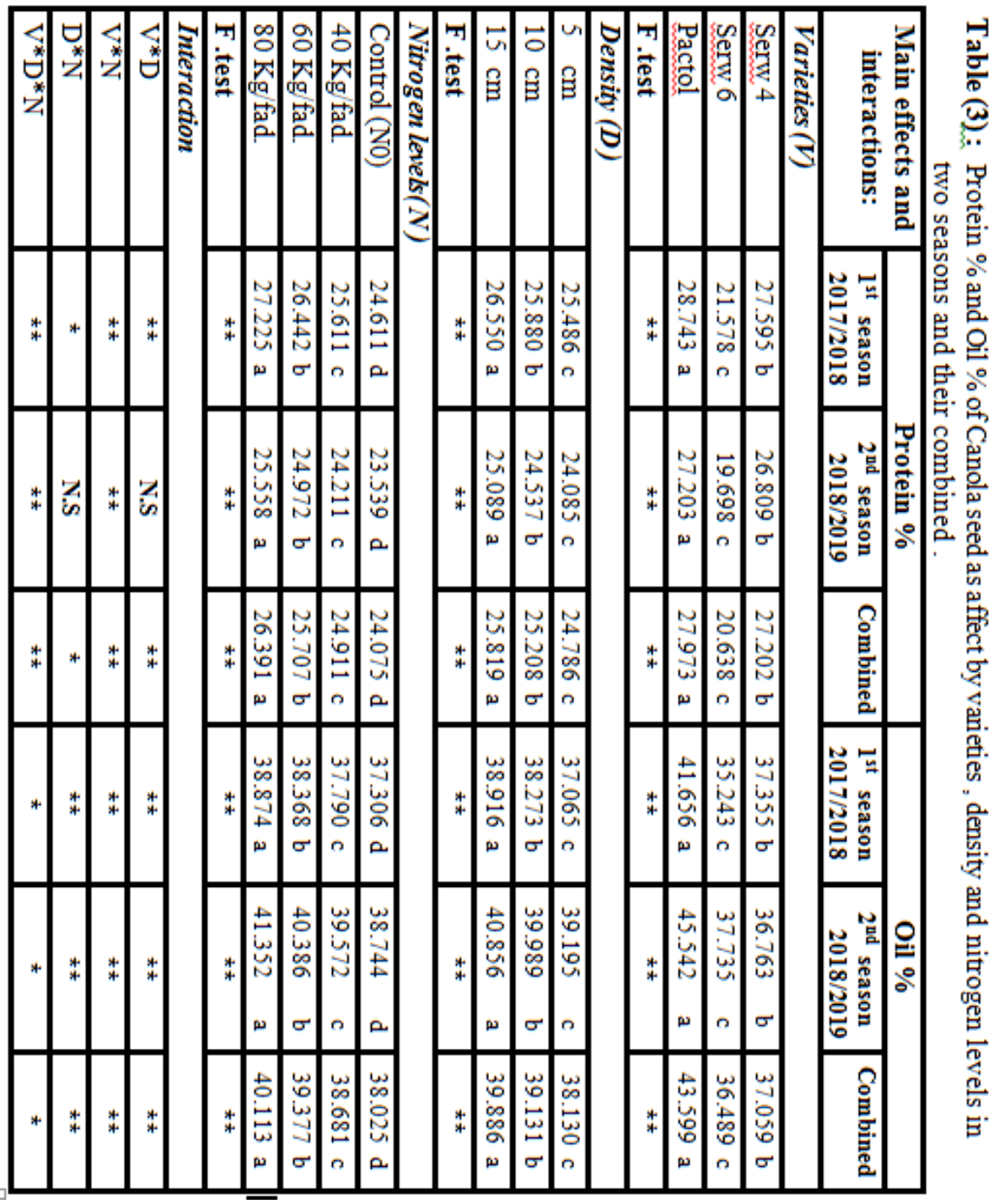


Table (3-a): Interaction effect between varieties and planting density (spacing inter rows) on protein \%. (Combined data).

\begin{tabular}{|c|c|c|c|}
\hline $\begin{array}{r}\text { Planting } \\
\text { density }\end{array}$ & $\begin{array}{c}\text { D1 } \\
5 \mathrm{CM}\end{array}$ & $\begin{array}{c}\mathrm{D2} \\
10 \mathrm{CM}\end{array}$ & $\begin{array}{c}\text { D3 } \\
15 \mathrm{CM}\end{array}$ \\
\hline Serw 4 & $\begin{array}{r}C \\
26.638\end{array}$ & $\begin{array}{c}\mathrm{B} \\
27.234\end{array}$ & $\begin{array}{c}\mathrm{A} \\
27.734\end{array}$ \\
\hline Serw 6 & $\begin{array}{r}C \\
20.346 \\
\end{array}$ & $\begin{array}{r}\text { B } \\
20.432 \\
\end{array}$ & $\begin{array}{c}\mathrm{A} \\
21.135 \\
\end{array}$ \\
\hline Pactol & $\begin{array}{r}\mathrm{C} \\
27.372\end{array}$ & $\begin{array}{r}\mathrm{B} \\
27.958\end{array}$ & $\begin{array}{c}\mathrm{A} \\
28.589\end{array}$ \\
\hline
\end{tabular}

Table $(\mathbf{3}-\mathbf{b})$ : Interaction effect between varieties and nitrogen levels on protein\%. (Combined data).

\begin{tabular}{|c|c|c|c|c|}
\hline $\begin{array}{r}\text { Nitrogen } \\
\text { levels }\end{array}$ & $\begin{array}{l}\text { N Zero } \\
\text { Control }\end{array}$ & $\begin{array}{c}\mathrm{N1} \\
40 \mathrm{Kg} / \mathrm{fad}\end{array}$ & $\begin{array}{c}\mathrm{N} 2 \\
60 \mathrm{Kg} / \mathrm{fad} .\end{array}$ & $\begin{array}{c}\mathrm{N3} \\
80 \mathrm{Kg} / \text { fad. }\end{array}$ \\
\hline Serw 4 & $\begin{array}{c}\text { D } \\
26.270\end{array}$ & $\begin{array}{rr}C & \\
26.645 & b\end{array}$ & $\begin{array}{c}\text { B } \\
27.722 \quad b\end{array}$ & $\begin{array}{c}A \\
28.170\end{array}$ \\
\hline Serw 6 & $\begin{array}{c}D \\
18.909\end{array}$ & $\begin{array}{c}\mathrm{C} \\
20.343 \\
\text { c }\end{array}$ & $\begin{array}{c}\text { B } \\
21.128\end{array}$ & $\begin{array}{c}\text { A } \\
22.170 \\
\text { c }\end{array}$ \\
\hline Pactol & $\begin{array}{c}\text { D } \\
27.045 \text { a }\end{array}$ & 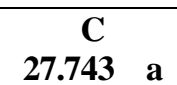 & \begin{tabular}{cc}
\multicolumn{1}{c}{ B } \\
28.271 & a
\end{tabular} & $\begin{array}{c}A \\
28.833 \\
\text { a }\end{array}$ \\
\hline
\end{tabular}

Table $(3-\mathbf{c})$ : Interaction effect between planting density (spacing inter rows) and nitrogen levels on protein \%. (Combined data).

\begin{tabular}{|c|c|c|c|c|}
\hline Nitrogen leve & $\begin{array}{l}\text { N Zero } \\
\text { Control }\end{array}$ & $\begin{array}{c}\mathrm{N1} \\
40 \mathrm{Kg} / \mathrm{fad} .\end{array}$ & $\begin{array}{c}\mathrm{N2} \\
60 \mathrm{Kg} / \text { fad. }\end{array}$ & $\begin{array}{c}\text { N3 } \\
80 \mathrm{Kg} / \\
\text { fad. }\end{array}$ \\
\hline D1 ( $5 \mathrm{~cm})$ & $\begin{array}{rr}\text { D } & \\
23.715 & \text { c }\end{array}$ & $\begin{array}{rr}C & \\
24.409 & \text { c }\end{array}$ & $\begin{array}{c}\text { B } \\
25.212 \text { c } \\
\end{array}$ & $\begin{array}{c}\text { A } \\
25.806 \\
\text { c }\end{array}$ \\
\hline D2 (10 cm) & $\begin{array}{c}\text { D } \\
23.902 \quad b\end{array}$ & $\begin{array}{c}C \\
24.920\end{array}$ & $\begin{array}{c}\text { B } \\
25.688 \quad \text { b }\end{array}$ & $\begin{array}{c}A \\
26.323\end{array}$ \\
\hline D3 (15 CM ) & $\begin{array}{c}\text { D } \\
24.607 \\
\end{array}$ & $\begin{array}{c}\text { C } \\
25.403 \text { a }\end{array}$ & $\begin{array}{c}\text { B } \\
26.222 \quad a\end{array}$ & $\begin{array}{c}A \\
27.045\end{array}$ \\
\hline
\end{tabular}


Table (3 - d): Interaction effect between varieties and planting density (spacing inter rows) on oil \%. (Combined data).

\begin{tabular}{|c|c|c|c|}
\hline$\underbrace{\begin{array}{c}\text { Planting } \\
\text { dens }\end{array}}_{\text {density }}$ & $\begin{array}{c}\text { D1 } \\
5 \text { CM }\end{array}$ & $\begin{array}{c}\text { D2 } \\
10 \mathrm{CM}\end{array}$ & $\begin{array}{c}\text { D3 } \\
15 \mathrm{CM}\end{array}$ \\
\hline Serw 4 & $\begin{array}{c}\mathrm{C} \\
35.990 \quad \mathrm{~b} \\
\end{array}$ & $\begin{array}{c}\mathrm{B} \\
37.165 \quad \mathrm{~b}\end{array}$ & $\begin{array}{cc}\mathrm{A} \\
38.021\end{array}$ \\
\hline Serw 6 & $\begin{array}{c}\mathrm{C} \\
35.978 \quad \mathrm{~b}\end{array}$ & $\begin{array}{c}\mathrm{B} \\
36.509 \mathrm{c}\end{array}$ & $\begin{array}{c}\mathrm{A} \\
36.979 \mathrm{c}\end{array}$ \\
\hline Pactol & $\begin{array}{c}\mathrm{C} \\
42.423 \quad \mathrm{a}\end{array}$ & $\begin{array}{c}\mathrm{B} \\
43.718 \quad a\end{array}$ & $\begin{array}{c}\mathrm{A} \\
44.657\end{array}$ \\
\hline
\end{tabular}

Table (3-e): Interaction effect between varieties and nitrogen levels on oil \%.

(Combined data).

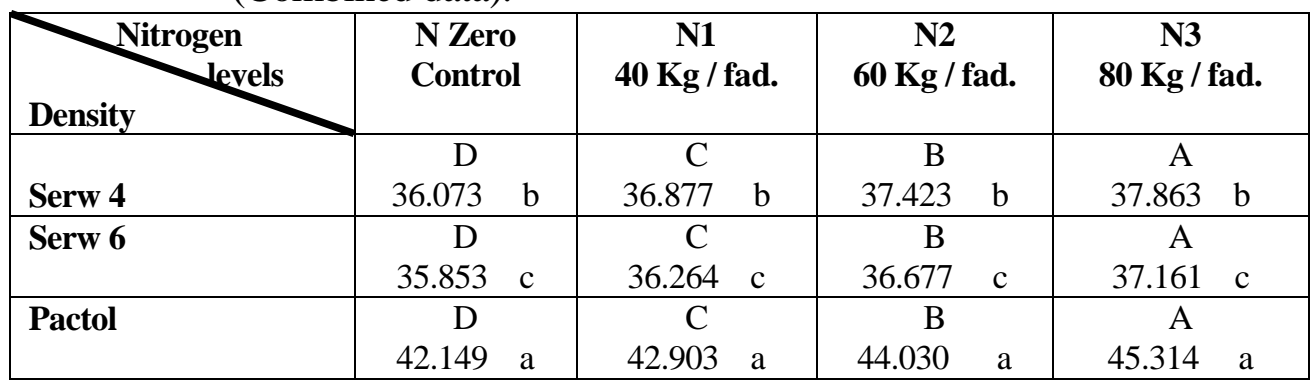

Table (3-f): Interaction effect between planting density (spacing inter rows) and nitrogen levels on oil \%. (Combined data).

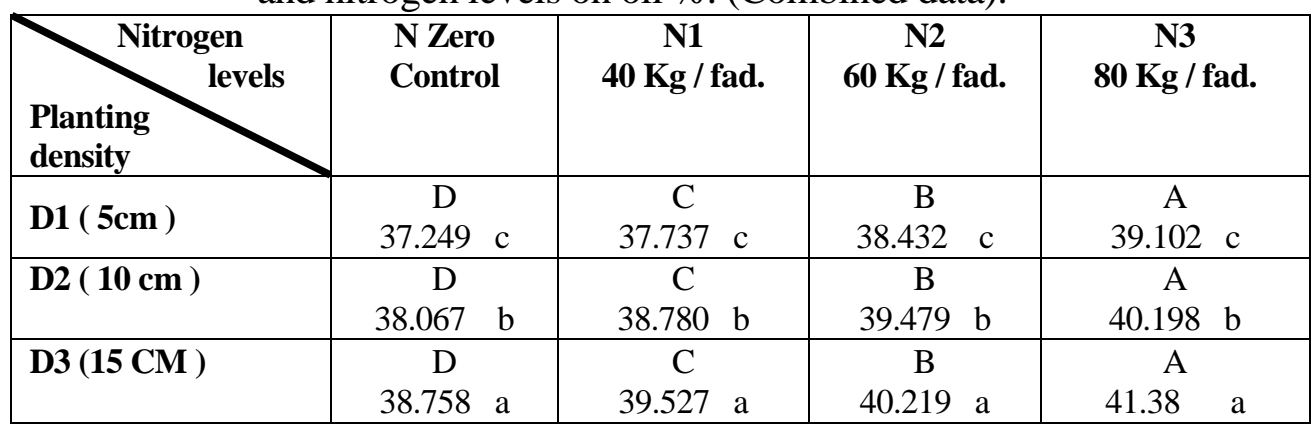

\section{Conclusion}

Nitrogen levels and plant densities significantly affected seed yield and it's components of Canola varieties evaluated.

An increase in both N-levels and plant densities, increased seed yield and it's components i.e., plant height, No. of branches / plant, straw yield, No. of pods / plant, No. of seeds / pod, 1000-seed weight, seed yield, protein and oil percentages. 


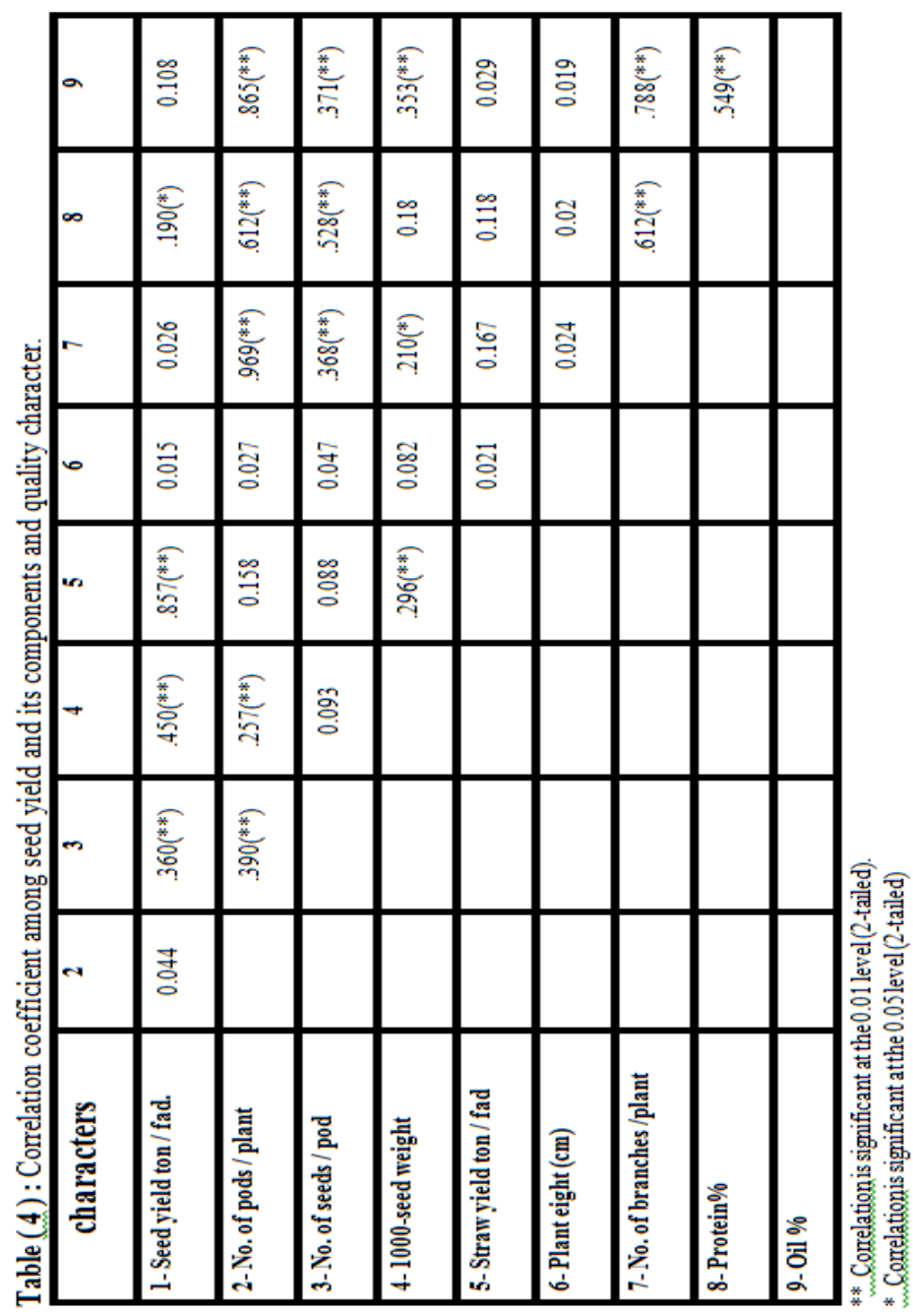




\section{REFERENCES}

A. O. A. C. (2005). Official Methods Of Analysis Association. Official Analytical Chemists.16 ${ }^{\text {ed }}$. Washington. D. C., 577-581.

Alam, J. E., Munsif, F., Ali, A. and Shah, A. (2018).Optimizing of Nitrogen for Yield and Yield Component of Rapeseed. International Journal of Environmental Sciences and Natural Resources, 11(4): 123-125.

Al-Doori, S. A. and Hasan, M.Y. (2010).Effect of row spacing and nitrogen fertilization on growth, yield and quality of some rapeseed Genotypes. J. Res. , 9(4): 531-550.

Al-Doori, S. A. (2011). A study of the importance of sowing dates and plant density affecting some rapeseed cultivars (Brassica napusL.). College Of Basic. Education Researches Journal, 11(1): 615-632.

Al-Doori, S. A. (2013). Response of yield, yield components and seed quality of some rapeseed genotypes (Brassica napus L.) to plant density under ainfed conditions. College of Basic Education Researches Journal, 12(4): 957-968.

Ali, H. G., Nadaf, S. K., Alkhamisi, S. A. and Al-Bakri, A. N. (2011).Adaptability of Canola (Brassica juncea) varieties in different regions of Oman. International Journal of Agriculture Biology, 13: 831-834.

Ali, S. S. (2020).Growth, Yield and Oil Quality of Canola (Brassica napusL.) Effect By Nitrogen Fertilizer and Seeding Rate. Plant Science and Molecular Biology,.9(3): 2168-9547.

Al-Solaimani, S. G. and Alghabari, F.(2015).Effect of Irrigation Quality and Different Rates of Nitrogen and Sulphur Fertilizers on Growth, Seed yield and Quality of Canola (Brassica napusL.) under Arid Environment of Saudi Arabia. International Journal of Applied Research and Studies (IJARS), (9): 2278-9480.

Al-Solaimani, S. G., Alghabari, F. and Ihsan, M. Z. (2015).Effect of different rates of nitrogen fertilizer on growth, seed yield, yield components and quality of Canola (Brassica napus L.) under arid environment of Saudi Arabia. International Journal of Agronomy and Agricultural Research, 6(4): 268-274.

Aminpanan,H. (2013). Effect of Nitrogen rate on seed yield, protein and oil content of two Canola (Brassica napus L.). Acta Agriculture Slovenicd, 101-str.183-190

Diepenbrock, W. (2000). Yield analysis of winter oil seed rape (Brassicanapus L.,).A. Review, Field Crops Res., 67:35-49 
Elewa, T. A., Mekki, B. B., Bakry, B. A. and El-Kramany, M. F. (2014). Evaluation of some introduced Canola (Brassica napusL.) varieties under different nitrogen fertilizer levels in newly reclaimed sandy soil. Middle East Journal of Scientific Research, 21(5): 746-755.

El-Nakhlawy,F.S. and Bakhashwain,A.A.(2009).Performance of Canola (Brassica napasL.)Seed Yield, Yield Components and Seed Quality under The Effects of Four Genotypes and Nitrogen Fertilizer Rates. Arid Land Agric. Sci., 20 (2): 33-47.

Eman, EL-Sarag, E. I. and Hassan, A. A. (2016).Substantial Fluctuating of Nitrogen Sources and Levels for Improving Canola Productivity in New Reclaimed Lands. Journal of Plant Production, 7(11): 1195-1200.

Farooq, M., Iqbal, S., Afridi, M. Z., Munsif, F., Tauseef, M. and Rehman, K. (2017).Optimization of nitrogen for increasing the productivity of Canola. Agri. Res. Tech, 3: 1-5.

Gao, J., Thelen, K. D., Min, D. H., Smith, S.,Hao, X. and Gehl, R. (2010). Effects of manure and fertilizer applications on Canola oil content and fatty acid composition. Agron. J., 102: 790-797.

Hozayn M. and Amal A. EL-Mahdy (2017).Evaluation of Yield and oil quality traits of some exotic Canola (Brassica napusL.) genotypes grown under sandy soil in Egypt. M. E. J of A. Sci., (7):1148-1156

Jackson, G. D. (2000).Effect of nitrogen and sulfer on Canola yield and nutrient uptake. Agronomy. J., 92 (4): 644-649.

Junior, E. A., Mertz, L. M., Henning, F. A., Quilón, I. R., Maia, M. D. S. and Altisent, J. M. D. (2012). Changes in Canola plant architecture and seed physiological quality in response to different sowing densities. Revista Brasileira de Sementes, 34: 14-20.

Kazemeini, S. A., Edalat, M., Shekoofa, A. and Hamidi, R. (2010). Effects of nitrogen and plant density on rapeseed (Brassica napusL.) yield and yield components in Southern Iran. J. Appl. Sci, 10(14):1461-1465.

Keivanrad, S. and Zandi, P. (2012).Effect of nitrogen levels on growth, yield and oil quality of Indian mustard grown under different plant densities. Thai Journal of Agricultural Science, 45(2): 105-113.

Keivanrad, S. and Zandi, P. (2014). Effect Of Nitrogen Levels On Growth, Yield and Oil Quality Of Indian Mustard Grown Under Different Plant Densities. Agronomical and Qualitative features of Indian, 1 (157):

ارقام الصفحات

Khayat, M. (2015).Measuring yield and its components of Canola geno-types in different planting date. Indian Journal of Fundamental and Applied Life Sciences, 5(2): 48-55. 
Kulachi, M.N.K., Jamalil, A. Z., Solangil, A.W., Siyall, M. A. ., Siyal, Z. A. and Raisl, N. (2016). Inter Grated effected of N. p. k and Bio-fertilizer on the growth and yield of Rape seed Varieties. Sci. Int. (Lahore), 28 (5): 4973-4979.

Ma, B. L., Biswas, D. K., Herath, A. W., Whalen, J. K., Ruan, S. Q., Caldwell, C., ... and Smith, D. L. (2015).Growth, yield, and yield components of Canola as affected by nitrogen, sulfur, and boron application. Journal of Plant Nutrition and Soil Science, 178(4): 658670.

Maha, M.S. El-Maleh., Belal, A. H. and EISarag, E. I. (2015). Response Of Some Canola Cultivars To Bio-fertilization Treatments Under North Sinai Conditions. Sinai Journal of Applied Sciences, 4(3): 197-204.

Malidarreh, G. A. (2010). Effects of nitrogen rates and splitting on oil content and seed yield of Canola (Brassica napusL.). American-Eurasian Journal of Agricultural and Environmental Science, 8(2): 161-166.

Mohamed, S. M., Mohamed, H. M., Shahata, H. M. and Ahmed, H. M. (2017).Growth, Yield and Yield Components of Canola Crop (Brassica napus L.) in El-Kharga Oasis New Valley as affected by bio, Nitrogen and Phosphorus Fertilization. Assiut Journal of Agricultural Sciences, 48: 319-330.

Mondal, M. M. A., Malek, M. A. and Bhuiyan, M. S. H. (2018). The role of morpho-physiological attributes on the seed yield of Brassica juncea. Acta Scientific Agriculture, 2(5), 22-26.

Mourad, K. A., Abdelraouf, E. A. and Elshall, S. A. (2021).Response of Canola Plant (Brassica napus L.)To Reducing Nitrogen Fertilizer Rates by Adding Humic Substance. Alexandria Science Exchange Journal, 42(January-March), 79-88.

Naderifar, M. and Daneshian, J. (2012). Effect of different nitrogen and biofertilizers effect on growth and yield of Brassica napus $\mathrm{L}$. International Journal of Agriculture and Crop Sciences (IJACS), 4(8): 478-482.

Naseri, R., Kazemi, E., Mahmoodian, L., Mirzaei, A. and Soleymanifard, A. (2012). Study on effects of different plant density on seed yield, oil and protein content of four Canola cultivars in western Iran. International Journal of Agriculture and Crop Sciences, 4(2): 70-78.

Ozer, H. (2003a). The effect of plant population densities on growth, yield and yield components of two spring rapeseed cultivars. Plant Soil and Environment, 49(9): 422-426. 
Riar, A., Gill, G. and McDonald, G. K. (2020).Rate of Nitrogen Rather Than Timing of Application Influence Yield and NUE of Canola in South Australian Mediterranean Environments. Agronomy, 10(10): 1505.

SAS Institute (2001). SAS/STAT User's Guide. Version 8.2.SAS Institute, Cary, USA.

Sattar, A., Cheema, M. A., Wahid, M. A., Saleem, M. F., Ghaffari, M. A., Hussain, S. and Arshad, M. S. (2013).Effect of sowing time on seed yield and oil contents of Canola varieties. Journal of Global Innovations in Agricultural and Social Sciences, 1(1), 1-4.

Shahin, Y. and Valiollah, R. (2009).Effects of row spacing and seeding rates on some agronomical traits of spring Canola (Brassica napus L.) cultivars. Journal of Central European Agriculture, 10(1): 115-121.

SPSS (2020).Statistical Package for Social Science, Version 20, Chicago, USA.

Taylor, A . J., Smith, C. J. and Wilson, I. B. (1991). Effect irrigation and nitrogen Fertilizer on yield, Oil content, nitrogen accumulation and water use of Canola ( Brassica napusL. ). Fert . Res . 29:249-260.

\section{دراسات تكنولوجية لبعض العمليات الزراعية

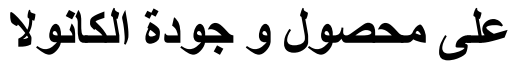 \\ آيه عزت عوض الثعراوي ـمها محمد عبدالله ــ السيد بيومي جاب الله}

قسم الإنتاج النباتي فرع المحاصيل ـ كلية التكنولوجيا والتنمية جامعة الزقازيق ـ مصر.

أجريت التجربة في مزرعة كلية التكنولوجيا والتنمية (منطقة غزالة ـ ـ مركز

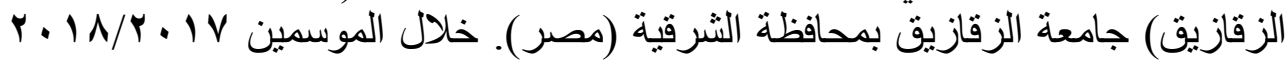
$r+19 / r \cdot 11$,

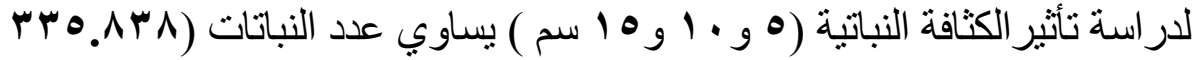

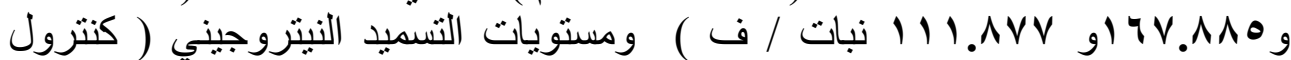

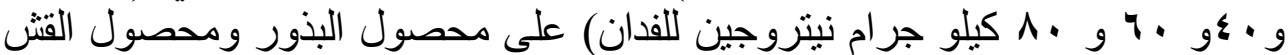

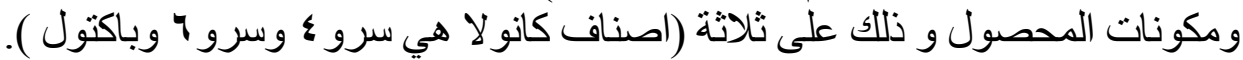
أنثارت النتائج أن الصنف باكتول أعطى أعلى النتائج العالية المعنوية مقارنة

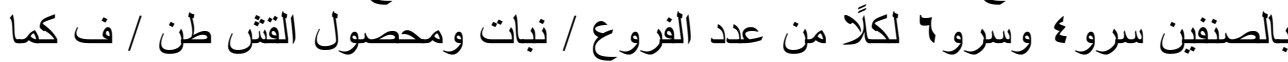

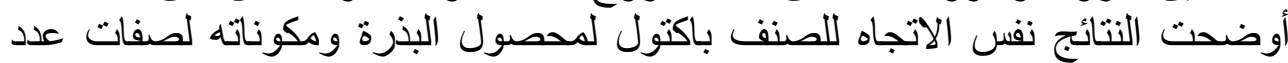


القرون / النبات وعدد البذور / القرن ووزن الألف بذرة ومحصول البذرة طن / ف ونسبة كلا من البروتين و الزيت.

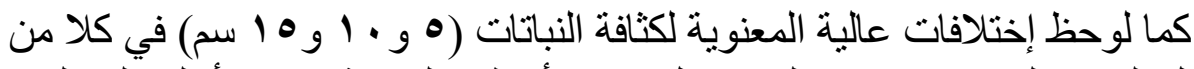

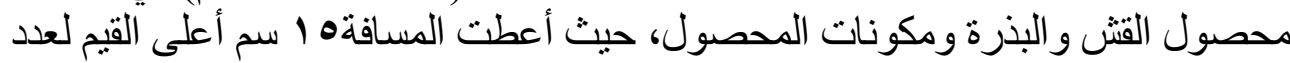

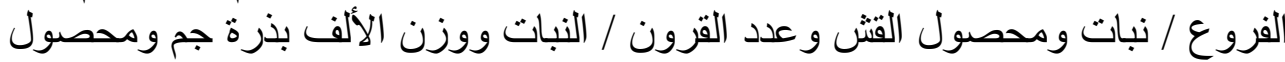
البذرة وكذللك نسبة البروتين و الزيت التيث.

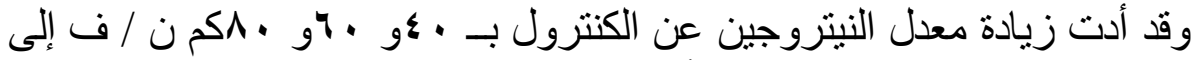

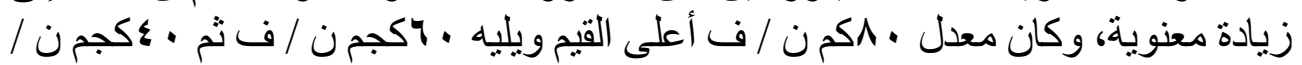

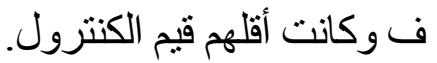

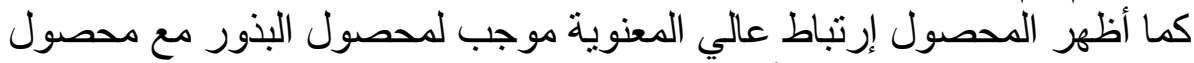

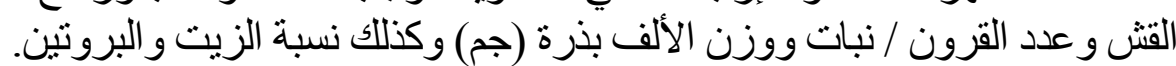

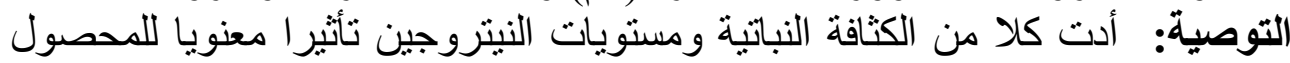

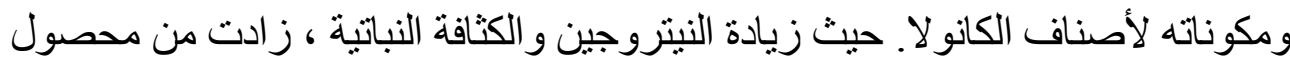

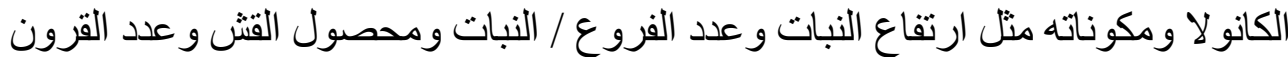

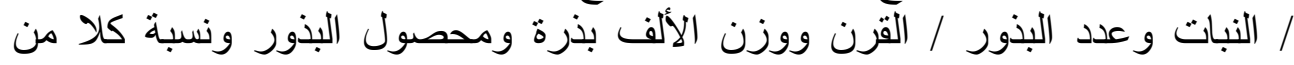

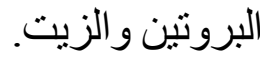

